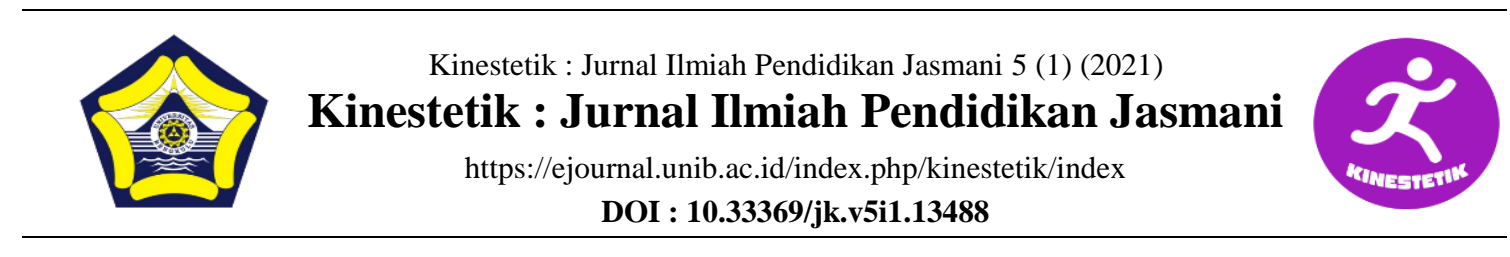

\title{
POINTING SKILLS TRAINING MODEL FOR PETANQUE ATHLETES
}

\author{
Ramdan Pelana*1, Yasep Setiakarnawijaya ${ }^{2}$, Dwie Anggraini ${ }^{3}$, Sukiri ${ }^{4}$, Intan \\ Safitri $^{5}$, Rizka Antoni ${ }^{6}$ \\ ${ }^{123456}$ Physics Education, Postgraduate, Universitas Negeri Jakarta, Jakarta, Indonesia
}

\begin{tabular}{l} 
Article Info \\
\hline Article History : \\
Received : November 2020 \\
Revised : February 2021 \\
Accepted : March 2021 \\
Available online : March \\
2021 \\
\hline
\end{tabular}

\section{Keywords:}

Development, model, pointing

\begin{abstract}
The aiming of this research and development is to produce training model of pointing skills for petanque athletes. Other than that, this research and development done for gaining in-depth information about developing and application training model of pointing skill, to knowing the effectivity, efficiency, and athlete's interest towards the training model. The method used in this research is Research and Development (R\&D) by Borg and Gall. The instrument used in this research and development are questionnaires and Petanque pointing skills test, which were used to collect data on the results of athletes pointing. The subject in this research and development were 30 athletes of DKI Jakarta club. The results in this study is a guidebook of pointing skills for petanque athletes with a total of 30 models that have been evaluated by experts, trials and revisions, and have been tested for their effectiveness. The effectiveness test used the "t-test" technique, data taken from the pre-test and post-test result with a significance level of 0.05 . Based on the result of the effectiveness test using the t-test, the difference in the results of the pointing skills between the pre test and post test obtained $t_{0}=14.159$ bigger than $t_{t}=0.000$, so the hypothesis is rejected. In conclusion, there is a significant difference between the pre-test and post-test of the skill of pointing on petanque. The average of pre-test on pointing skills was 3.77 smaller than the post-test average of 7 . This can be concluded that the pointing skills training model for petanqque athletes is effectively applied in training at the petanque sports club.
\end{abstract}




\section{INTRODUCTION}

The achievements of athletes in sports are not only achieved without a training process. The training process carried out by athletes must be followed with seriousness. It will be impossible for athlete to get an achievement if the athlete is not serious doing the training process and will cause the skill to not develop.

To improve athlete's skills, coaches must have variety of training models with different level so that they are not monotonous. Coaches who give the same training model repeatedly and monotonously will saturate the athletes, so that they cannot achieve an increase in getting a performance in each exercise. Coaches are required to always be smart in seeing athletes' difficulties when they are playing in a competition. Because what happens in a match is sometimes different from what has been trained. This often heppens in petanque sports athletes.

Petanque itself is a form of boules game that aims to throw an iron ball as close as possible to a wooden ball called a cochonnet / jack / boka and the feet must be in a circle. Petanque comes from the Occitan language "Les Pen Tanco" which means feet close to the ground or base and is a sport that originated in France. Petanque sport is a sport that is competed in almost all developed countries on all continents.

Petanque sport is a sport of accuracy and require someone to fully understand about accuracy also dominate the characteristics of the field. Because this game can be played on hard ground, grass, sand or other soil surfaces. In addition, a petanqu player/athlete must clearly know the basic techniques in this sport so that they master these skills.

In petanque sport, there are several basic techniques that must be mastered, specifically pointing and shooting. The pointing technique is a technique of bringing an iron ball closer to a target or a small ball made of wood. Meanwhile, the shooting technique is a technique to keep the opponent's iron ball away from the small ball target.

Petanque is a new sport in Indonesia. Petanque starts in Indonesia around the 2000 s and officially competed in Indonesia at $26^{\text {th }}$ SEA GAMES in 2011. Although it is classified as a new sport, the petanque sport is currently experiencing very rapid development. It is proven that currently 25 provinces have been inaugurated and become official sports at the 2020 Pekan Olahraga Nasional (PON) in Papua.

DKI Jakarta is one of the provinces that will participate in the upcoming PON in Papua 2020. Recently, Petanque DKI Jakarta has carried out the next stage of selection to filter the potential and skills possessed by Petanque athletes in DKI Jakarta.

In this selection, all athletes must test their pointing, shooting skills and single games. From the results of this selection, almost all athletes in the selection had small score in the pointing skill test.

Whereas, according to Zaini Lisa in Pilus (2017) "shooting and pointing are basic skills that are important in petanque" (Pilus, Amin, Din, \& Muhammad, 2017). So every athlete must have good skills in both. Because when in a match if the shooting managed to be decreases under certain conditions, the athlete will prefer to use the pointing technique. So that pointing skills need to be trained by every athlete to cover up the lack in shooting success.

Pointing exercises are needed from the researcher's point of view. So far there is still a lack of training models so that it seems monotonous to improve the throwing skills of athletes themselves. So that mistake are still happened repeatedly and make the strategy not work during the 
match. Therefore, the researcher took the initiative to conduct a study entitled "Pointing Skill Training Model for Petanque Athletes". Researchers aim to increase the variety of pointing exercises so that they are not monotonous and can handle difficulties and problems during matches.

Pointing Petanque Skills

According to Faizal Chan (2012)

"Training is an activity that is carried out systematically and planned to improve body function". In sports activities, training is useful for improving skills (Chan, 2012). Meanwhile, according to Bompa (2009) "Training is a systematic activity over a long period of time, gradually and individually, aimed at forming a human who functions physiology and psychologically to meet the demands of the task."(Bompa \& Haff, 2009).

Based on the description above, it can be concluded that training is an activity that is carried out continuously by going through a systematic, repetitive process, with the addition of training load and intensity. Then it is carried out in a planned manner so as to achieve the goal of the exercise, namely skills.

Cherly A. Coker (2004) "Skills are simply defined as the ability to carry out tasks that have specific goals to be achieved (Coker, 2004). Meanwhile, William H. Edwards (2010) defines "skill is a measure of the success of the quality of movement and produces the correct constant motion to achieve certain goals" (Edwards, 2010). Furthermore, according to Widiastusti (2014) "movement skills are the ability to perform movements efficiently, as well as the embodiment of the quality of coordination and control over the parts of the body involved in movement" (Widiastuti, 2014).

So skill is a person's ability to carry out a movement with the goals to be achieved and can also be interpreted as a intentional, systematic, and sustainable effort to adaptively carry out complex activities.

John Honeybourney (2006) "Skills are used to describe the motor movements of a person who has achieved excellence in his activities. An athlete who is considered skilled often has the qualities of coordination, ability, control, and efficiency of movement" (Honeybourney, 2006).

Judith E. Rink (2010) "Learning movement skills, has different characteristics from cognitive and affective learning. Singer citing Fitts and Posner's opinion that there are three stages that must be carried out by someone learning movement skills, i.e.: (1) the cognitive stage, (2) the associative stage, and (3) the automation stage." (Rink, 2010). So when someone wants to do an activity, skills are important things that someone must have so that when doing these activities the movements carried out can be well structured. Nachim in Tri Sutrisna (2018) "Petanque sport is a sport of agility of throwing a ball made of iron by bringing the target ball closer and moving the opponent's ball (target), and both feet are in the circle" (Tri, Moch, \& Ramdan, 2018). Ardo Okilanda et al (2018) Petanque is played on a field size 4 $\mathrm{m} \times 15 \mathrm{~m}$ above hard ground or grass" (Okilanda et al., 2018). According to Tri Moch and Ramdan (2018) "Petanque sports can be played anywhere, as long as they are on hard ground, but it is not recommended to play on grass or concrete. Petanque requires a spin of the ball to stop the ball rolling" (Tri et. al, 2018).

Turkmen in Gustopo Harry and Siti (2017)"Petanque comes from France. Petanque has various names that differ in each country. Bocce is the name petanque in Turkey and Bowls is the name in England"(Laksana, Pramono, \& Mukarromah, 2017). In Sudiadharma and 
Abdul Rahman (2017) "The original form of this sport appeared in 1907 in La Ciotat, in Provence, a city in southern France" (Sudiadharma \& Rahman, 2017). At that time the sport of petanque was played only by French aristocrats, along with the development of the petanque era it began to be played by all groups and was an achievement sport that was contested in almost all developed countries throughout the continent.

Petanque is a new sport in Indonesia. Petanque starts in Indonesia around the 2000s and the exact year is undefined. Ardo Okilanda (2018) "Petanque officially competed in Indonesia at SEA GAMES XXVI in Palembang, Indonesia and the establishment of Federasi Olahraga Petanque Indonesia on March 18, 2011"(Okilanda, 2018). Although it is classified as a new sport, the petanque sport is currently experiencing very rapid development. It is proven that currently 25 provinces have been inaugurated by Federasi Olahraga Petanque Indonesia (FOPI) and become official sports at the 2020 Pekan Olahraga Nasional (PON) in Papua.

Ramdan Pelana (2016) "The basic skill of petanque is throwing, there are 2 (two) types of throws in petanque sports, namely pointing and shooting" (Pelana, 2016). Wahyu W and Hafidz (2018) "Shooting is a form of effort to keep the opponent's iron ball away from the target as far as possible to get a score" (Widodo \& Hafidz, 2018). Kharim (2018) "Pointing in petanque sports can be said to be a technique of delivering an iron ball with the aim of being close to the target, the wooden ball"'(Kharim \& Nurkholis, 2018). B. W. Puttman (2011) "In performing the correct pointing skill, the bosi is held with the entire palm of the hand and clenched into a fist without any space on the knuckles. So that the throw results can be perfect and reach the target" (Puttman, 2011).
In pointing skills, athletes can do throws with various training models for pointing skills in petanque. According to Juhanis Benny and Masjumi (2017) "There are several ways to do the pointing technique: roll (roll), half / soft lob (medium soar), and high lob (high soar)" (Juhanis, B, \& Nur, 2017).

a.) Roll is throwing the ball less than 3 (three) meters from the circle, where the ball is rolled along the arena Rolling approaching the target boka.

Figure 1. Pointing Roll Source: Personal Documentation

Pointing rolling is usually done by athletes in Indonesia in a squatting position then the body and shoulders are tilted forward.

b.) Half/Soft lob is tossing the ball a little higher forming a curve and the bosi falls and rolls to the target boka.

Half Lob

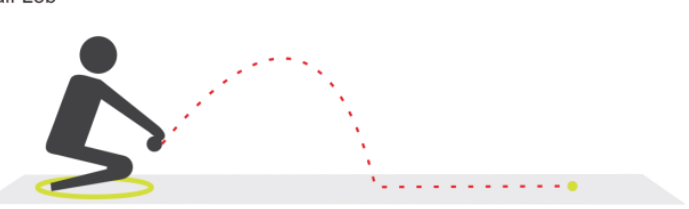

Figure 2. Pointing Half Lob

Source: Personal Documentation

Pointing half lob is a natural way to throw or deliver an iron ball. This technique is widely used not only for one field character but also for several types of field characters. Smith in Kharim (2018) "Therefore this technique is more widely used by athletes when playing petanque sports" (Kharim et. al, 2018). This pointing is usually done by athletes in Indonesia in a squatting or standing 
position then the body and shoulders are slightly inclined forward.

c.) High lob/lob is to throw the bosi higher vertically, the bosi falls and rolls closer to the target boka.

Lob

Figure 3. Pointing Lob

Source: Personal Documentation

This High Lob Pointing can be done in a squatting or standing position. Athletes in Indonesia predominantly do it in a standing position, but there are some athletes who can do it in a squatting position. The position of the torso and shoulders is slightly upright when throwing because it requires a higher vertical throw.

According to Iwan Hermawan (2012) "Throwing in petanque sports uses a parabolic throw. Thereby to produce precise throw requires a good kinesthetic ability to estimate the precise angle and also the strength to throw." (Hermawan, 2012).

When doing a pointing throw implies 2 movements, shoulder flexion and wrist flexion. When a player swings the ball backward, it is called a shoulder extension motion and when swinging forward it is called a shoulder flexion motion. When a player grips the ball it is called the wrist flexion motion, while the ball is released it is called the wrist extension movement.

According to Soufe (2015) "Backswing in petanque sports is an prefix movement in pointing, which is moving the arm backward across the body axis. Release pointing is when the ball leaves the hand, when the ball is released at the right time it will affect the height and speed of the ball" (Soufe, 2015). Knowing the mistakes in the movement and motion of the ball will create the ideal movement, knowing the mistakes in performing techniques completely and accurately, will create athletes who have the potential to become champion.

Some things that must be done in the pointing technique:

1. Grip (How to hold the ball)

When holding the ball your fingers and palms should be tight but not gripping the ball tightly, the ball just sticks to the knuckles, so that when throwing the ball it will be easily directed to follow the direction of the finger joints and get good ball alignment.

\section{Arm (Lengan)}

The source of power or the axis of the pointing technique lies in the swing of the arm, there are two core movements when throwing the ball, the backswing and the forward swing, the resulting motion is like a pendulum motion, the backward swing must be slower until it reaches the peak of the swing then proceed with the forward swing which has a greater speed than the backward swing, when doing the forward swing there is no flinching of the arm. Backswing in petanque is the prefix movement in pointing, which is moving the arm backward through the body axis.

3. Wrist

Besides from grip, the wrist also affects the results of the pointing technique, the opening in the wrist adds energy and results in the height of the ball which determines the angle of the throw, with the wrist opening of the ball that is thrown will experience rotation (back spin). According to Kharim (2018) "Release during pointing is when the ball leaves the hand, when the ball is released at the right time will affect the height and speed of the ball (Kharim et. al, 2018). 
When pointing, it adds more backspin control, keeping the ball on the track straighter and prevent it from too far away.

\section{Body Posture}

In pointing technique, it can be done by squatting and standing. Some players squat down so they can see the contours of the field and determine the point of dropping the ball. Usually used at shorter distances. While standing is often used for longer distances or if squatting is uncomfortable.

\section{Leg and Feet (Feet Position)}

In Soufe (2015) "The origin of the word petanque is pieds tanques which means feet are attached to the ground, so if there is a lump in the footwear it must clean up or clean up the soil surface until it is completely in comfortable" (Soufe, 2015). There are several positions of the legs when doing the pointing technique, one of the most efficient position is when the foot supports same as the hand that throws the ball, if the throw uses the right hand, the right foot is the support and vice versa, it is intended that the position of the body has a balance.

\section{METHODS}

The method used in this research is Research and Development (R\&D) by Borg and Gall on the development of a pointing skill training model for athletes in Petanque with a pre-experimental effectiveness test in the form of a one group pretest-posttest design.

Table 1. Research Design in Effectiveness Test

\begin{tabular}{cccc}
\hline Subject & $\begin{array}{l}\text { Pre- } \\
\text { Test }\end{array}$ & Treatment & $\begin{array}{c}\text { Post- } \\
\text { Test }\end{array}$ \\
\hline $\mathrm{R}$ & $\mathrm{O}_{1}$ & $\mathrm{P}$ & $\mathrm{O}_{2}$ \\
\hline
\end{tabular}

\section{RESULT AND DISCUSSION}

1. Must answer research problems in the form of: (a) results of needs analysis, (b) results of justification and validation of development products carried out by experts, and (c) test of product effectiveness.

2.Data exposure should follow development procedures

3. The data presented.

To test the effectiveness of the application of the Petanque pointing skills training model used the "t-test", data from the pretest and posttest pointing petanque skills using the $t$ test at the significance level $=0.05$. Here are the results of calculations are presented in the table.

Tabel 2. Paired Sample Statistics

\begin{tabular}{|c|c|c|c|c|c|}
\hline & & Mean & $\mathbf{N}$ & $\begin{array}{c}\text { Std. } \\
\text { Deviation }\end{array}$ & $\begin{array}{l}\text { Std. } \\
\text { Error } \\
\text { Mean }\end{array}$ \\
\hline \multirow[t]{2}{*}{$\begin{array}{c}\text { Pair } \\
1\end{array}$} & $\begin{array}{c}\text { Post- } \\
\text { test }\end{array}$ & 7.00 & 30 & 2.213 & .404 \\
\hline & $\begin{array}{l}\text { Pre- } \\
\text { test }\end{array}$ & 3.77 & 30 & 1.924 & .351 \\
\hline
\end{tabular}

Tabel 3. Paired Sample Correlation

\begin{tabular}{cccrc}
\hline & & N & Correlation & Sig. \\
\hline $\begin{array}{c}\text { Pair } \\
1\end{array}$ & $\begin{array}{c}\text { Post-test \& pre- } \\
\text { test }\end{array}$ & 30 & .826 & .000 \\
\hline
\end{tabular}

Table 4. Summary of test results pointing petanque effectiveness skills with t-test

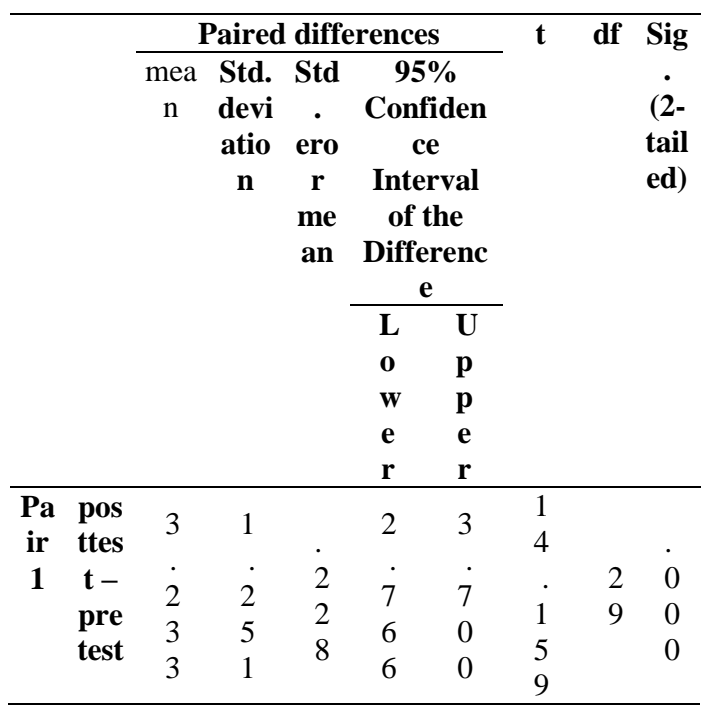


Based on the output using SPSS 22, the mean value of the Petanque pointing results before being given the training model is 3.77 and after being given treatment with the exercise model is 7 it means that the mean value of the Petanque pointing results has increased. The result of the training correlation coefficient before and after being given the Petanque pointing model is 0.826 with a p-value of $0.00<0.05$ so the conclusion is significant. In the t-test using SPSS 22, the result of $\mathrm{t}$ count $=14.159, \mathrm{df}=29$ and $\mathrm{p}$-value $=0.00$ $<0.05$, which means that there is a significant difference in athlete's pointing training before and after the Petanque sport pointing training model treatment.

Based on this information, it can be said that the developed training model for pointing skills for athletes in Petanque.

\section{DISCUSSION}

\section{Product Improvement}

Based on the numbers in tables 2, 3, and 4 above, it can be concluded that the pointing skills training model for petanque athletes is proper to use in petanque pointing training and effective for improving athlete's pointing ability. There is a comparison of numbers that show that the results of the pre-test and post-test have progressed, from the pre-test mean of 3.77 then given treatment in the form of pointing training models that have been developed then post-test is then held to determine the effectiveness of the developed model and obtained mean of 7 , so this petanque pointing training model is effective for developing pointing skill training for petanque athletes.

Seeing the strength and weakness of the products made, there are inputs that researchers will convey in order to achieve improvements to this product, as for the input is as follows:

a) The adjustment of the training model of pointing petanque given to the characteristics of the field, also repetition of training is required so that the athlete really understands the characteristics of the field and the training model being carried out.

b) The different characteristics and understanding of athletes require the coach to provide an explanation and practice directly so that they understand to learn new movements to do.

2. Product Discussion

The petanque pointing model made by the researcher is a product that aims to assist the trainer in delivering petanque pointing exercise material, to improve athlete's pointing ability and as a reference for training materials. This pointing model is made based on the level of needs of athletes in training activities, especially pointing techniques in petanque training for athletes.

After being reviewed about several weaknesses, this product needs some improvements, then some of the advantages of this product can be conveyed, including:

a) Increase pointing for petanque athletes.

b) This model can make athletes more active, and enthusiastic in petanque pointing exercises.

c) Petanque pointing model is more effective and efficient.

d) To assist coaches in training athletes in clubs.

e) Contribution to science, especially sports education.

f) This petanque pointing model is carried out systematically from easy to difficult things.

g) This model can be seen in the form of modules or books.

The product weaknesses that need to be addressed including:

a) The product used is far from perfect. 
b) The explanation and graphics in this pointing exercise model is far from perfect.

\section{CONCLUSION}

Therefore it can be concluded that the pointing skills training model for athletes in the Petanque sport can be developed and and applied in training pointing skills for petanque athletes and with the pointing skill training model for petanque athletes can practice pointing effectively and efficiently.

\section{REFERENCES}

Chan, F. (2012). Strength Training (Latihan Kekuatan). Cerdas Sifa, 1(1), 1-8.

Edwards, William H. (2010). Motor Learning and Control From Theory To Paractice. California State University: Sacramento.

Hermawan, Iwan. (2012). Gerak Dasar Permainan Petanque. Jakarat: Kemenpora Deputi 4.

Juhanis, B, B., \& Nur, M. (2017). Pelatihan Teknik Dasar dan Sosialisasi Peraturan Permaian Olahraga Petanque pada Mahasiswa FIK UNM Makassar. Pengabdian Kepada Masyarakat Universitas Negeri Makassar, 1(1), 137-141.

Kharim, M. A., \& Nurkholis. (2018). Analisis Backswing dan Release Ketepatan Pointing Half Lob Jongkok pada Jarak 7 Meter Olahraga Petanque. Prestasi Olahraga, 1(3), 1-6.

Laksana, G. B., Pramono, H., \& Mukarromah, S. B. (2017). Perspektif Olahraga Petanque dalam Mendukung Prestasi Olahraga Jawa Tengah Abstrak. Physical Education and Sports, 6(1), 36-43.

Okilanda, A. (2018). Revitalisasi Masyarakat Urban/Perkotaan Melalui Olahraga Peatanque. Ilmu Keolahragaan, 1(1), 86-98.

Okilanda, A., Arisman, Lestari, H., Lanos, M. E. C., Fajar, M., Putri, S. A. R., \& Sugarwanto. (2018). Sosialisasi
Petanque Sebagai Olahraga Masa Kini. Bagimu Negeri, 2(1), 69-76.

Pelana, R. (2016). Hubungan Kekuatan Otot Tungkai Dan Keseimbangan Statis Dengan Hasil Shooting Pada Atlet Klub Petanque. Prosiding Seminar Nasional Maret 2016, 116-127.

Pilus, A. M., Amin, M. N. M., Din, A., \& Muhammad, N. (2017). The Effect of Sport Technology on StudentAthletes'Petanque Skill Performance. Applied Engineering Research, 12(17), 6591-6596.

Putmwan, B. W. (2011). Petanque The Greatest Game You Never Heard Of. French.

Rink, Judith E. (2010). Teaching Physical Education forLearning, 6th Edition. New York: McGraw-Hill Co., Inc.

Souef, Gilles. (2015). The Winning Trajectory. Franch : Copymedia.

Sudiadharma, \& Rahman, A. (2017). Pengembangan Olahraga Permainan Petanque pada Siswa SMA di Makassar. Pengabdian Kepada Masyarakat Universitas Negeri Makassar, 1(1), 413-415.

Tri, S., Moch, A., \& Ramdan, P. (2018). Model Latihan Keterampilan Shooting Olahraga Petanque Untuk Pemula. Universitas Negeri Jakarta, 1(2), 4653.

Widiastuti. (2011). Tes dan Pengukuran Olahraga. Jakarta: PT. Bumi Timur Jaya.

Widodo, W., \& Hafidz, A. (2018). Kontribusi Panjang Lengan, Koordinasi Mata Tangan, dan Konsentrasi Terhadap Ketepatan Shooting Pada Olahraga Petanque. Prestasi Olahraga, 3(1), 1-6.

Yarmani, Y., \& Defliyanto, D. (2020). Petanque Sports Training And Socialization For Pjok Teachers In Mgmp Sukaraja, Kab. Seluma. Dharma Raflesia: Jurnal Ilmiah Pengembangan Dan Penerapan Ipteks, 18(1), 12-14. 